\title{
Esophageal Anastomotic Stricturotomy: Electroincision Therapy with a Needle Knife
}

\author{
João Fernandes ${ }^{a, b}$ Diogo Libânio ${ }^{a, c}$ Sílvia Giestas ${ }^{a}$ José Ramada ${ }^{a}$ \\ David Martinez-Ares $^{a}$ Jorge Canena ${ }^{d}$ Luís Lopes ${ }^{a, e, f}$

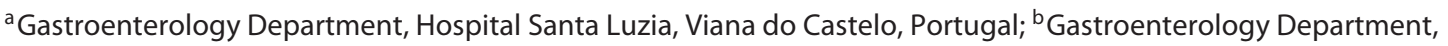 \\ Centro Hospitalar Cova da Beira EPE, Covilhã, Portugal; ' ${ }^{C}$ Gastroenterology Department, Instituto Português de \\ Oncologia do Porto Francisco Gentil, Porto, Portugal; ${ }^{d}$ Gastroenterology Department, Hospital Cuf Infante Santo, \\ Lisbon, Portugal; 'Life and Health Sciences Research Institute (ICVS), School of Medicine, University of Minho, \\ Braga, Portugal; ${ }^{\mathrm{f} I C V S} / 3 B^{\prime}$ s - PT Government Associate Laboratory, Braga/Guimarães, Portugal
}

Keywords

Esophageal anastomotic stenosis · Stricturotomy · Needle knife Balloon dilation

\section{Estriturotomia de anastomose esofágica: Incisão com needle knife}

\section{Palavras Chave}

Estenose de anastomose esofágica · Estriturotomia ·

Needle knife · Dilatação com balão

Esophageal anastomotic strictures develop in 5-46\% of the patients after surgical resection [1]. The resulting dysphagia has a strong impact on the quality of life of these patients, precluding an adequate food intake [2]. Dilation therapy has been the cornerstone of treatment for esophageal strictures, and its success ranges from 70 $90 \%$, although up to $40 \%$ of the patients require more than 3 dilation sessions $[1,3]$. However, there is a small

\section{KARGER}

E-Mail karger@karger.com www.karger.com/pig
(C) 2018 Sociedade Portuguesa de Gastrenterologia Published by S. Karger AG, Basel

Karger

Open access

This article is licensed under the Creative Commons AttributionNonCommercial-NoDerivatives 4.0 International License (CC BYNC-ND) (http://www.karger.com/Services/OpenAccessLicense). Usage and distribution for commercial purposes as well as any distribution of modified material requires written permission. group of patients with refractory or recurrent stenosis, in which there is an inability to achieve a $14-\mathrm{mm}$ esophageal diameter despite 5 dilation sessions at 2-week intervals, or after achieving the 14- $\mathrm{mm}$ target, this diameter is not sustained over a 4-week interval [4]. In this subset of patients, additional treatment modalities are required.

Incisional therapy with a needle knife is an excellent rescue strategy in short anastomotic esophageal strictures when performed by skillful endoscopists; it can be repeated up to 3 times, if necessary [3]. Additionally, the use of stents could be another alternative $[1,3,5]$, especially in refractory stenosis longer than $1 \mathrm{~cm}$ and in stenosis where the incision therapy was unsuccessful. However, in this patient, given the small length of the stenosis $(<1 \mathrm{~cm})$, the use of stents would carry a relatively high risk of migration.

We aim to demonstrate the usefulness of incisional therapy in the management of a complex refractory and recurrent esophageal anastomotic stenosis (online suppl. video; for all online suppl. material, see www.karger.com/ doi/10.1159/000489722). Before being referred to our de- 


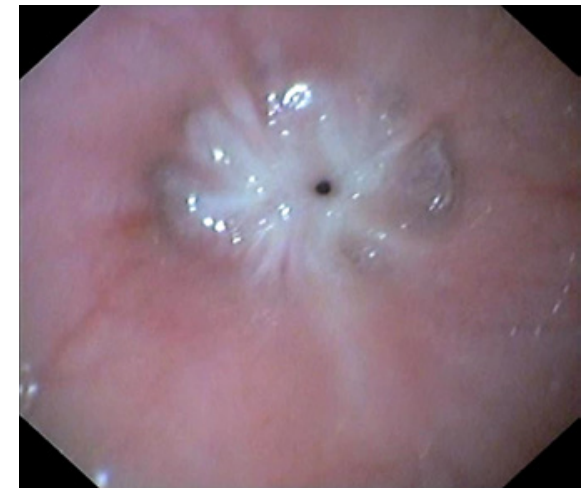

Fig. 1. Identification of a pinhole fibrotic stenosis ( $2 \mathrm{~mm}$ wide), $35 \mathrm{~cm}$ from the incisors.

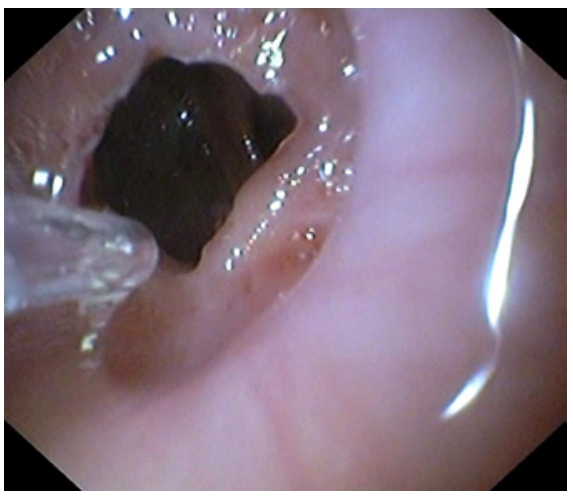

Fig. 2. Endoscopic view after incision of the fibrotic stenosis with a needle knife.

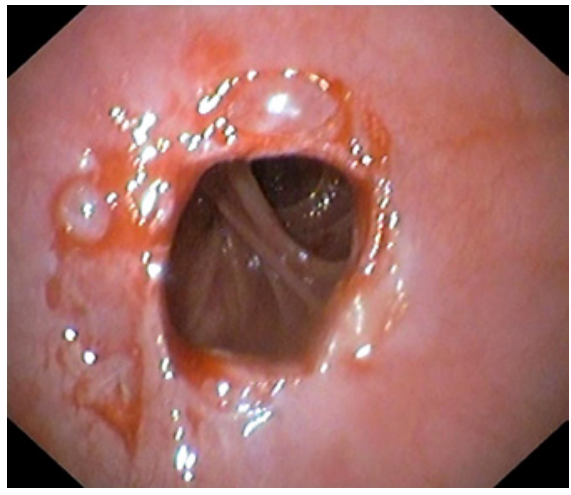

Fig. 3. View after complementary balloon dilation; complete destruction of the fibrotic ring. partment, the patient underwent a total of 8 dilation sessions using balloons and Savary dilators in another institution, including triamcinolone acetonide injection. At our center, an upper gastrointestinal endoscopy was performed, revealing a pinhole fibrotic stenosis ( $2 \mathrm{~mm}$ wide), $35 \mathrm{~cm}$ from the incisors (Fig. 1). The fibrotic ring was incised in the 4 quadrants with a needle knife using Endocut I (40 W, effect 2) by an experienced endoscopist (L.L.) (Fig. 2), allowing the passage of the gastroscope through the anastomosis. Additionally, dilation with a balloon to a diameter of $18 \mathrm{~mm}$ was done in the same session (Fig. 3). She has been seen in our outpatient clinic for six years, with no recurrence of symptoms and without requiring additional endoscopic treatments.

The incisional therapy seems to be a safe and effective treatment in the management of refractory anastomotic strictures, provided it is performed in tertiary centers by experienced interventional endoscopists because of its potential complications and the endoscopic interven- tional skills required. There are scarce multimedia articles reporting incisional therapy, especially in pinhole esophageal anastomotic stenosis.

\section{Statement of Ethics}

This study neither required informed consent nor review/approval by the appropriate ethics committee.

\section{Disclosure Statement}

The authors declare that they have no conflicts of interest to disclose.

\section{Author Contributions}

J.F. and L.L. wrote the manuscript. D.L., S.G., J.R., D.M.-A., and J.C. were responsible for the revision of its contents.
References
1 Samanta J, Dhaka N, Sinha SK, Kochhar R: Endoscopic incisional therapy for benign esophageal strictures: technique and results. World J Gastrointest Endosc 2015;7:13181326.

2 Muto M, Ezoe Y, Yano T, Aoyama I, Yoda Y, Minashi K, et al: Usefulness of endoscopic radial incision and cutting method for refractory esophagogastric anastomotic stricture (with video). Gastrointest Endosc 2012;75: 965-972.
3 Siersema PD, de Wijkerslooth LR: Dilation of refractory benign esophageal strictures. Gastrointest Endosc 2009;70:1000-1012.

4 Kochman ML, McClave SA, Boyce HW: The refractory and the recurrent esophageal stricture: a definition. Gastrointest Endosc 2005; 62:474-475.

5 Canena JMT, Liberato MJA, Rio-Tinto RAN, Pinto-Marques PM, Romão CMM, Coutinho AVMP, et al: A comparison of the temporary placement of 3 different self-expanding stents for the treatment of refractory benign esophageal strictures: a prospective multicentre study. BMC Gastroenterol 2012;12:70. 